\title{
Physical Development and Renal Functions in Adolescents Consuming Drinking Water with High Content of Vital Cation
}

\author{
Aizman $\mathrm{RI}^{1,2 *}$, Nedovesova $\mathrm{SA}^{1}$, Golovin $\mathrm{MS}^{1}$, lashvili $\mathrm{MV}^{1}$ and Trofimovich $\mathrm{EM}^{2}$ \\ ${ }^{1}$ FSBEI HE, Department of anatomy, physiology and life safety, Novosibirsk State Pedagogical University, Novosibirsk, Russia \\ ${ }^{2}$ FBUN, Novosibirsk SRI Hygiene, Rospotrebnadzor, Novosibirsk, Russia
}

*Corresponding author: Aizman Roman, Doctor of Biological Sciences, Professor, Honored scienti t of Russia, Head of the Department of anatomy, physiology and life safety, Novosibirsk State Pedagogical University, Novosibirsk, Russia, Tel: +79139119564; E-mail: aizman.roman@yandex.ru

Received: 16 Aug, 2018 | Accepted: 24 Sep, 2018 | Published: 02 Oct, 2018

Citation: Aizman RI, Nedovesova SA, Golovin MS, lashvili MV, Tro movich EM (2018) Physical Development and Renal Functions in Adolescents Consuming Drinking Water with High Content of Vital Cations. J Environ Toxicol Stud 2(2): dx.doi. org/10.16966/2576-6430.115

Copyright: (c) 2018 Aizman RI, et al. This is an open-access article distributed under the terms of the Creati e Commons Attributio License, which permits unrestricted use, distribution, and reproduction in any medium, provided the original author and source are credited.

\section{Summary}

The article presents the data concerning the influence of drinking water with high content of vital catio $s$ on the physical development and renal functions in adolescents of 10-12 years old. It has been found the marked decrease of physical health and development and changes in osmo-and ionuretic renal functions, reflec ed in the increasing of diuretic and ionuretic response in conditions of spontaneous urination, and a er water loading. Evaluation of the sodium-potassium ratio in saliva demonstrated the rigidity of hormonal mechanisms of sodium-potassium homeostasis regulation following the consumption of hard drinking water, which was manifested in the absence of changes the parameter a er the water load, whereas in the control group, this ratio decreased, reflectin the acti ation of orti osteroid mechanisms.

Keywords: Drinking water; Sodium; Calcium; Magnesium; Physical development of adolescents; Renal function; Sodiumpotassium ratio in sali a

\section{Introduction}

According to the water strategy adopted by the Government of the Russian Federation for the period up to 2020 [1], access of the population to safe drinking water is recognized as a task of national scale. Despite this, the problem of providing the population with drinking water of good quality remains one of the determining factors for the majority of the country. In 52 regions of the Russian Federation [2] the imbalance in the macro and microelement composition of drinking water is a key issue related to the impact of the water factor and requiring a comprehensive solution to preserve the health of the population. Thus, according to sanitary and hygienic studies conducted by the Novosibirsk center for hygiene and epidemiology in 2016 in the Novosibirsk region there were identified 10 areas unfavorable for mineralization and hardness of drinking water, one of which is the Vengerovo district (Table 1).

It should be noted that ionized minerals of drinking water have high rates of physiological activity, biological availability and absorption. Therefore, even relatively small concentrations of minerals introduced into drinking water can give a pronounced physiological effect $[3,4]$.

Deficit and imbalance of $\mathrm{Ca}^{2+}$ and $\mathrm{Mg}^{2+}$ can be considered as potential risk factors for urolithiasis, skin diseases, cardiovascular system and digestive organs [5-9]. One of the main effectors of homeostatic regulation of magnesium and calcium balance are kidneys [10-14], while data on the impact of excess $\mathrm{Ca}^{2+}$ and $\mathrm{Mg}^{2+}$ in drinking water on the functional state of various organs and systems of the growing organism are much less [15].

In this regard, the aim of this research was to study the level of physical development and physical health, as well as kidney functions in pupils of 10-12 years in conditions of long-term consumption of drinking water with high content of sodium, calcium and magnesium.

\section{Materials and Methods}

Healthy children (boys and girls of 10-12-years-old) who did not have at the time of examination acute diseases were selected for physiological and hygienic examination of the physical development.

According to the generally accepted methods, basic anthropometric indicators (height, body mass, chest circumference, strength of hand and back muscles) were measured and different indices relatively to body mass were calculated [16,17]. Functional parameters of cardiorespiratory system (heart rate, arterial blood pressure, reaction of cardiovascular system to physical load, vital capacity of lungs, vital index) were determined by the program of complex health assessment, on the basis of which the integral level of physical health was assessed [18]. Renal functions at rest and following $1 \%$ of body mass water loading were evaluated in accordance with the guidelines of the Ministry of health of the USSR of 28.12.83 [19].

Concentrations of $\mathrm{Na}^{+}$and $\mathrm{K}^{+}$ions in urine and saliva were determined by flame photometry (BWB-XP Flame Photometer, $\mathrm{UK}$ ); concentrations of $\mathrm{Ca}^{2+}$ and $\mathrm{Mg}^{2+}$ ions were determined by 
Table 1: Indicators of drinking water quality in the settleme ts of the Novosibirsk region in 2016

\begin{tabular}{|c|c|c|c|}
\hline \multirow{2}{*}{$\begin{array}{l}\text { No } \\
n / n\end{array}$} & \multirow{2}{*}{ Indices } & \multicolumn{2}{|c|}{ Concentration, $\mathrm{mg} / \mathrm{dm}^{3}$} \\
\hline & & Verkh-Irmen & Vengerovo \\
\hline 1 & Sodium & $61,17 \pm 6,12$ & $224,6 \pm 22,5^{*}$ \\
\hline 2 & Potassium & $\leq 0,50$ & $\leq 0,50$ \\
\hline 3 & Calcium & $65,93 \pm 4,35$ & $80,76 \pm 5,29 *$ \\
\hline 4 & Magnesium & 37,54 & 55,08 \\
\hline 5 & Iron & $0,12 \pm 0,30$ & $1,65 \pm 0,29 *$ \\
\hline 6 & Manganese & $\leq 0,01$ & $0,20 \pm 0,05$ \\
\hline 7 & $\begin{array}{l}\text { Mineralization (d y } \\
\text { residue) }\end{array}$ & $493,00 \pm 59,20$ & $1114,00 \pm 111,40^{*}$ \\
\hline 8 & Total hardness & $6,38 \pm 0,96$ & $8,56 \pm 1,28$ \\
\hline
\end{tabular}

Note: *signifi ant di erences at $\mathrm{p} \leq 0.05$ between water indices in VerkhIrmen and Vengerovo (data of Verkh-Irmen are presented as control)

biochemical analysis (BS-200E analyzer, China). Statistical analysis of the results was carried out by methods of variation statistics using the parametric Student's t-test, as well as standard programs of Microsoft Office; the differences between measured parameters of children from both schools were considered significant at $\mathrm{p} \leq 0.05$.

\section{Research Results}

The assessment of the integral level of physical health of the surveyed pupils showed the higher health indicators in children of the Verkh-Irmen school, while a larger number of pupils from the Vengerovo School had a low health level (Table 2).

The analysis of morphofunctional parameters of girls of VerkhIrmen school showed that all relative values of physical development (indeces) corresponded to age and regional standards. At the same time, these data were lower for girls in Vengerovo district, which were due to the low absolute values of parameters. Similar differences were observed in boys (Table 3). Thus, the described results indicated a lower level of health and morphofunctional parameters of Vengerovo school pupils.

One of the most informative methods for assessing kidney functions is a functional test with water load. Table 4 presents the main indicators of osmo-and ionoregulatory renal functions in the conditions of relative rest in the morning on an empty stomach (background) and 2 hours after intake of $1 \%$ of body mass water loading.

In conditions of high content of ions in drinking water, pupils have demonstrated the increased diuretic renal function already in background samples. At the same time, after the water loading the examined children from Vengerovo had higher reactivity of the renal response (there was a more pronounced increase in diuresis and excretion of sodium, calcium and especially urea). It can indicate a high reactivity of osmo-and ion-regulating mechanisms. It is also impossible to exclude that the increased excretion of ions was due to the higher intake with drinking water (Table 1). Described differences in renal response in children of these districts could be due to different levels of hormonal activity of the adrenal cortex, involved in the regulation of ionic balance. One of the indicators reflecting the activity of corticosteroid hormones in the blood is the sodium-potassium ratio of saliva. It was used to exclude the stress that can occur during blood collection in children [20].

As can be seen from table 5, in the children from Vengerovo district, where the concentration of sodium in drinking water was 5 times higher than its content in the control area, the background level of sodium-potassium ratio was higher than the control values, that
Table 2: The distribution of children in Verkh-Irmen and Vengerovo schools by physical health (\%).

\begin{tabular}{|l|l|l|l|l|l|l|l|}
\hline \multicolumn{2}{|c|}{ Levels/Groups } & n & Low & $\begin{array}{c}\text { Below } \\
\text { average }\end{array}$ & Average & $\begin{array}{c}\text { Above } \\
\text { average }\end{array}$ & High \\
\hline $\begin{array}{l}\text { Verkh-Irmen } \\
\text { (control) }\end{array}$ & Girls & 40 & 50,5 & 35,5 & 10,5 & 3,5 & 0,0 \\
\cline { 2 - 8 } & Boys & 40 & 36,5 & 43,5 & 20,0 & 0,0 & 0,0 \\
\hline $\begin{array}{l}\text { Vengerovo } \\
\text { (observation }\end{array}$ & Girls & 26 & 75,5 & 24,5 & 0,0 & 0,0 & 0,0 \\
\cline { 2 - 8 } & Boys & 35 & 47,0 & 50,5 & 2,5 & 0,0 & 0,0 \\
\hline
\end{tabular}

Table 3: Morphofunctional indices in pupils of Verkh-Irmen and Vengerovo schools $(\mathrm{M} \pm \mathrm{m})$

\begin{tabular}{|c|l|l|l|l|}
\hline \multicolumn{2}{|c|}{$\begin{array}{c}\text { Parameters/ } \\
\text { Groups }\end{array}$} & $\begin{array}{c}\text { Index of the } \\
\text { strength of the } \\
\text { muscles of the } \\
\text { hands (carpal), } \\
\text { kg/kg }\end{array}$ & $\begin{array}{c}\text { Vital index, } \\
\mathbf{m l} / \mathbf{k g}\end{array}$ & $\begin{array}{c}\text { Index of the } \\
\text { strength of the } \\
\text { back muscles, } \\
\text { kg/kg }\end{array}$ \\
\hline \multirow{2}{*}{ Verkh-Irmen } & Girls & $50,1 \pm 2,7$ & $46,9 \pm 1,8$ & $0,9 \pm 0,1$ \\
\cline { 2 - 5 } & Boys & $55,9 \pm 3,0$ & $48,8 \pm 2,3$ & $1,17 \pm 0,08$ \\
\hline Vengerovo & Girls & $44,0 \pm 2,5^{*}$ & $36,0 \pm 2,4^{*}$ & $0,7 \pm 0,1^{*}$ \\
\cline { 2 - 6 } & Boys & $49,5 \pm 2,7^{*}$ & $36,9 \pm 2,4^{*}$ & $1,04 \pm 0,07$ \\
\hline
\end{tabular}

Note: *signifi ant di erences at $p \leq 0,05$ : compared to the corresponding data of Verkh-Irmen pupils.

indicated a reduced production (or activity) of aldosterone and was due to a higher sodium content in the saliva of the examined children.

After the water loading in children of Verkh-Irmen there was a significant decrease in the sodium-potassium ratio of saliva, which indicated an increase in the concentration of corticosteroid hormones (primarily, aldosterone), that under normal conditions caused a decrease in sodium excretion from the body to preserve osmotic homeostasis after water intake [21-24].

However, the sodium-potassium ratio after water load in children from Vengerovo did not change significantly compare to its background level, indicating a weak hormonal response to water intake. This may testify the rigidity of hormonal mechanisms regulating sodiumpotassium homeostasis in conditions of prolong consumption of hard drinking water.

Thus, the analysis of diuretic and ionuretic kidney reaction in children living in different areas and consuming drinking water with different content of sodium, calcium and magnesium salts indicates the adaptive response of renal functions depending on the ion composition of drinking water. It reflects the effect of the used water on the mechanisms of homeostatic regulation of renal functions. However, long-term impact on the system probably causes the tension and leads to its exhaustion or rigidity of the hormonal mechanisms of ion balance regulation.

\section{Conclusion}

Analysis of all these parameters gives the reason to believe that drinking water with high hardness and mineralization of sodium, magnesium and calcium salts has an adverse effect on the level of physical health and morphofunctional indicators of children, as well as adaptation of the osmo-and ion-regulating renal functions, but causing the rigidity or exhaustion of corticosteroid hormonal mechanisms regulating ion homeostasis. 
Table 4: Indicators of renal functio $s$ in children of Verkh-Irmen and Vengerovo in conditions of relati e rest and in 2 hours a er the intake of $1 \%$ water load $(\mathrm{M} \pm \mathrm{m})$.

\begin{tabular}{|c|c|c|c|}
\hline \multicolumn{2}{|c|}{ Indicators } & $\begin{array}{l}\text { Verkh-Irmen } \\
\quad(n=19)\end{array}$ & $\begin{array}{l}\text { Vengerovo } \\
(n=25)\end{array}$ \\
\hline \multirow{2}{*}{$\begin{array}{l}\mathrm{V} \\
\mathrm{ml} / \mathrm{min}^{*} \mathrm{~m}^{2}\end{array}$} & background & $0,59 \pm 0,03$ & $1,43 \pm 0,15^{\wedge}$ \\
\hline & a er water load & $1,57 \pm 0,11^{*}$ & $2,14 \pm 0,19 * \boldsymbol{\Lambda}$ \\
\hline \multirow{2}{*}{$\begin{array}{l}\text { GFR, } \\
\mathrm{ml} / \mathrm{min}^{*} \mathrm{~m}^{2}\end{array}$} & background & $52,09 \pm 2,76$ & $113,38 \pm 15,39^{\mathbf{\Delta}}$ \\
\hline & a er water load & $39,78 \pm 1,77^{*}$ & $36,31 \pm 2,11^{*}$ \\
\hline \multirow{2}{*}{$\begin{array}{l}\% \mathrm{RH}_{2} \mathrm{O} \\
\%\end{array}$} & background & $98,82 \pm 0,17$ & $98,61 \pm 0,15$ \\
\hline & a er water load & $95,87 \pm 0,50 *$ & $93,77 \pm 0,54 * \Delta$ \\
\hline \multirow{2}{*}{$\begin{array}{l}\text { Uosm, } \\
\text { mosm/l }\end{array}$} & background & $667,11 \pm 38,01$ & $805,20 \pm 47,51^{\wedge}$ \\
\hline & a er water load & $272,72 \pm 40,28^{*}$ & $260,06 \pm 33,83^{*}$ \\
\hline \multirow{2}{*}{$\begin{array}{l}\text { UosmV, } \\
\mathrm{mcmol} / \mathrm{min}^{*} \mathrm{~m}^{2}\end{array}$} & background & $355,30 \pm 21,06$ & $1113,48 \pm 152,33^{\Delta}$ \\
\hline & a er water load & $294,11 \pm 16,66^{*}$ & $463,49 \pm 35,91 * \Delta$ \\
\hline \multirow{2}{*}{$\begin{array}{l}\text { UNa V, } \\
\mathrm{mcmol} / \mathrm{min}^{*} \mathrm{~m}^{2}\end{array}$} & background & $98,67 \pm 6,28$ & $242,80 \pm 32,92^{\mathbf{\Delta}}$ \\
\hline & a er water load & $45,47 \pm 5,62 *$ & $62,98 \pm 8,48^{*}$ \\
\hline \multirow{2}{*}{$\begin{array}{l}\text { UCa V, } \\
\mathrm{mcmol} / \mathrm{min}^{*} \mathrm{~m}^{2}\end{array}$} & background & $0,50 \pm 0,03$ & $3,69 \pm 0,53^{\mathbf{\Delta}}$ \\
\hline & a er water load & $0,20 \pm 0,04^{*}$ & $0,56 \pm 0,15^{* \mathbf{\Lambda}}$ \\
\hline \multirow{2}{*}{$\begin{array}{l}\text { UMg V, } \\
\mathrm{mcmol} / \mathrm{min}^{*} \mathrm{~m}^{2}\end{array}$} & background & $1,26 \pm 0,08$ & $2,77 \pm 0,32^{\wedge}$ \\
\hline & a er water load & $0,75 \pm 0,06 *$ & $0,83 \pm 0,13^{*}$ \\
\hline \multirow{2}{*}{$\begin{array}{l}\text { Uurea V, } \\
\mathrm{mcmol} / \mathrm{min}^{*} \mathrm{~m}^{2}\end{array}$} & background & $90,3 \pm 4,4$ & $1210,2 \pm 157,3^{\mathbf{\Delta}}$ \\
\hline & a er water load & $102,40 \pm 6,80 *$ & $264,75 \pm 31,4 * \boldsymbol{\Delta}$ \\
\hline \multicolumn{2}{|c|}{$\begin{array}{l}\% \text { of urine output for } 2 \text { hours a er } \\
\text { water loading }\end{array}$} & $65,62 \pm 2,54$ & $79,00 \pm 6,00^{\wedge}$ \\
\hline
\end{tabular}

Note: signifi ant di erences at $\mathrm{p} \leq 0.05: 1 .{ }^{*}$ signifi ant di erences compared with background urine samples;

2. $\Delta$ signifi ant di erences of indicators between Verkh-Irmen and Vengerovo.

Table 5: Concentration of sodium, potassium and sodium-potassium ratio of saliva in the examined children from Verkh-Irmen and Vengerovo $(\mathrm{M} \pm \mathrm{m})$.

\begin{tabular}{|c|c|c|c|}
\hline \multicolumn{2}{|c|}{ Indicators } & $\begin{array}{c}\text { Verkh-Irmen } \\
\quad(n=19)\end{array}$ & $\begin{array}{c}\text { Vengerovo } \\
(n=25)\end{array}$ \\
\hline \multirow{2}{*}{$\mathrm{Na}, \mathrm{mcmol} / \mathrm{l}$} & background & $7,55 \pm 0,97$ & $11,86 \pm 0,25^{\wedge}$ \\
\hline & a er water load & $5,29 \pm 0,83^{*}$ & $11,54 \pm 0,41^{\wedge}$ \\
\hline \multirow{2}{*}{$\mathrm{K}, \mathrm{mcmol} / \mathrm{l}$} & background & $16,7 \pm 0,73$ & $13,40 \pm 0,35^{\wedge}$ \\
\hline & a er water load & $24,05 \pm 0,42$ & $10,98 \pm 0,23^{\wedge}$ \\
\hline \multirow{2}{*}{$\mathrm{Na} / \mathrm{K}$} & background & $0,45 \pm 0,10$ & $0,88 \pm 0,13^{\mathbf{\Delta}}$ \\
\hline & a er water load & $0,22 \pm 0,08^{*}$ & $1,05 \pm 0,05^{\Delta}$ \\
\hline
\end{tabular}

Note: signifi ant di erences at $\mathrm{p} \leq 0.05$ : 1 . *signifi ant di erences compared with background urine samples;

2. $\Delta$ signifi ant di erences of indicators between Verkh-Irmen and Vengerovo.

\section{References}

1. Water strategy of the Russian Federation for the period up to 2020: approved by the Order of the Government of the Russian Federation from 27.08.2009. No 12, 1-35.

2. Onishchenko GG, Zaitseva NV, May IV, Andreeva EE (2016) Cluster systemati ation of parameters of sanitary and epidemiologic wellbeing of the population of regions of the Russian Federation and the cities of Federal value. Preventi e medicine: actual aspects of health risk analysis 1: 4-14.

3. Bulatov VP, Ivanov AV, Rylova NI (2004) Influence of long-term drinking water consumption of unfavorable mineral composition. Pediatrics 1: 71-74.
4. Konshina LG, Lezhnin VL (2014) Assessment of drinking water quality and risk for health of population. $\mathrm{H}$ giene and sanitation 3: 5-10

5. Catling LA, Abubakar I, Lake IR, Swift L, Hunter PR (2008) A systematic review of analyti al observational studies investi ating the association between cardiovascular disease and drinking water hardness. J Water Health 6: 433-442.

6. Ulubieva EA, Avtandilov AG (2016) E ect of magnesium on the cardiovascular system in women. Rational pharmacotherapy in cardiology 12: 87-93.

7. Leurs LJ, Schouten LJ, Mons MN, Goldbohm RA, van den Brandt PA (2010) Relationship between tap water hardness, magnesium, and calcium concentration and mortality due to ischemic heart disease or stroke in The Netherlands. Environ Health Perspect 118: 414-420.

8. Maslov DV, Nechukhaeva EM, Afanasieva-Grigorieva SI (2005) Hygienic estim tio of quality of centralized drinking water supply in Primorsky Krai. In: Results and prospects of scientifi researches on the problem of human ecology and environmental hygiene, Research Institu e of human ecology and environmental hygiene by Sysin, 174-179.

9. Morris RW, Walker M, Lennon LT, Shaper AG, Whincup PH (2008) Hard drinking water does not protect against cardiovascular disease: new evidence from the British Regional Heart Study. Eur J Cardiovasc Prev Rehabil 15: 185-189.

10. Natochin YV (1976) lonoregulatory kidney function. Federal State Unitary Enterprise "Academic Scientific-Publishi , Production and Printing and Boo selling Center Nauka" (Moscow), 268.

11. Pantyukhin IV, Finkinshtein YD (1977) Refl $x$ mechanisms maintaining magnesium homeostasis. Bull Exp Biol Med 84: 7-11.

12. Shutskaia JV, Shakhmatova EI, Kuznetsova AA, Natochin YV (2008) Role of the kidneys in regulation of osmolality and concentrations of cations in the blood serum in hyperglycemia. Human Physiology 5: 73-79.

13. Wasana HM, Perera GD, Gunawardena PS, Fernando PS, Bandara J (2017) WHO water quality standards Vs Synergic e ect(s) of fluoride, heavy metals and hardness in drinking water on kidney tissues. Sci Rep 7: 42516.

14. Zinov'eva VN, lezhitsa IN, Spasov AA (2007) Magnesium homeostasis: mechanisms and inherited disorders. Biomed Khim 53: 683-704.

15. Tselikh ED (2010) Modeling of environmental vital factors that determine the health status of adolescents of the KhabarovskyKrai. Scientifi notes of Transbaikalian State University. Series: Biological Sciences 79-85.

16. Kosovanova LV, Mel'nikova MM, Aizman RI (2003) The Screeningdiagnostics of health of pupils and students of Novosibirsk. Siberian University Publishing House 240.

17. Reznikov KM (2011) On the constants of body fluids and criteria of drinking water. In: Ecological Geology: theory, practice and regional problems materials of the Second International scientific- acti al conference 310-314.

18. Aizman RI, Lebedev AV, Aizman NI, Rubanovich VB (2017) Screening Diagnostics of Human's Health Using the IT-Technologies is the Base of Preventi e Medicine. Adv Tech Biol Med 5: 219.

19. Aizman RI, Velikanova LK (1983) The development of renal functions and water-salt metabolism in ontogeny. Zentralblattfü Pharmazie, Pharmakotherapie und Laboratoriumsdiagnostik 122: 1299-1303

20. Kolpakov MG (1978) Mechanisms of corti osteroid regulation of body functions. $\mathrm{N}$ vosibirsk: Science, 200. 
21. Aizman RI (1983) Age Peculiarities of the Reaction of the Organism on De-And Hyperhydration. Human P ysiology 9: 454-460.

22. Aizman RI, Kalmykova NE, Borisova SA, Petrovna SI (1980) Age Specifics of Water-Salt Exchange in Children and the Influence of Some Factors of Environment on them. Pediatrics 2: 13-27.

23. Aizman RI, Nedovesova SA, Trofim vich EM (2016) Influence of drinking water with various contents of magnesium on biochemical parameters of blood plasma of rats. Bulletin of Tuvan State University 2: 24-28.

24. Krasheninina GI, Trofim vich EM, Ayzman RI (2004) The influence of highly mineralized drinking water on the health and kidney function of the children of the Novosibirsk region and Altai. Nephrology and dialysis 6: 314-318. 